\title{
Exposure of Humans to Attacks by Deer Keds and Consequences of Their Bites-A Case Report with Environmental Background
}

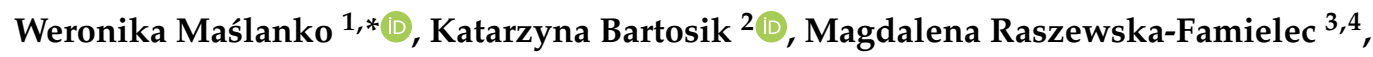 \\ Ewelina Szwaj ${ }^{5}$ and Marek Asman ${ }^{6}$ (D) \\ 1 Department of Animal Ethology and Wildlife Management, Faculty of Animal Sciences and Bioeconomy, \\ University of Life Sciences in Lublin, Akademicka 13 St., 20-950 Lublin, Poland \\ 2 Chair and Department of Biology and Parasitology, Faculty of Health Sciences, Medical University of Lublin, \\ Radziwiłłowska 11 St., 20-080 Lublin, Poland; katarzyna.bartosik@umlub.pl \\ 3 Department of Cosmetology, Faculty of Physical Education and Health, University of Physical Education, \\ Akademicka 2 St., 21-500 Biała Podlaska, Poland; magdalena.raszewska-famielec@awf-bp.edu.pl \\ 4 NZOZ Med-Laser Dermatology Clinic, Młyńska 14A St., 20-406 Lublin, Poland \\ 5 Ignacy Jan Paderewski Primary School Number 43 in Lublin, Śliwińskiego 5 St., 20-861 Lublin, Poland; \\ szwajewelina@gmail.com \\ 6 Department of Parasitology, Faculty of Pharmaceutical Sciences in Sosnowiec, Medical University of Silesia, \\ Jedności 8 St., 41-200 Sosnowiec, Poland; masman@sum.edu.pl \\ * Correspondence: weronika.maslanko@up.lublin.pl; Tel.: +48-814456831
}

Received: 5 November 2020; Accepted: 1 December 2020; Published: 3 December 2020

Simple Summary: Lipoptena species, also named the deer ked or deer fly, are commonly encountered in temperate areas of Europe, northern China, and North America. Although wild animals seem to be the preferred hosts of these parasitic arthropods, it is increasingly being noted that humans are also directly threatened by their bites. Skin lesions evolving after Lipoptena bites are painful and often lead to the development of inflammation of the skin. Lipoptena species also pose a threat to the health of the host by transferring pathogenic factors, e.g., Bartonella schoenbuchensis, Borrelia burgdorferi, and Anaplasma phagocytophilum. For this reason, knowledge of symptoms caused by Lipoptena bites is worth promoting among not only scientists but also the general public.

Abstract: Insects of the genus Lipoptena, e.g., Lipoptena cervi and Lipoptena fortisetosa, are hematophagic ectoparasites mainly attacking deer, roe deer, moose, horses, and cattle. Humans may also be incidental hosts for these insects. The species are vectors of numerous pathogens, including Bartonella schoenbuchensis, Borrelia burgdorferi, and Anaplasma phagocytophilum. Due to the short time of feeding on humans, usually painless bites, and an initially small trace at the site of the bite, the symptoms reported by the patient may not be associated with deer ked infestation and infection with pathogens transmitted by these arthropods. The aim of the study was to describe the consequences of $L$. cervi bites in humans with detailed documentation of the development of skin lesions. The knowledge about skin lesions arising after deer ked bites may be useful in clinical practice for monitoring patients for the presence of pathogens transmitted by the parasites.

Keywords: deer ked bites; deer ked dermatitis; Lipoptena cervi; wild cervids; ectoparasites; blood-sucking arthropods

\section{Introduction}

Arthropods from the Hippoboscidae family are obligate parasites of mammals and birds. The Hippoboscidae family includes three subfamilies: Ornithomyinae, Hippoboscinae, 
and Lipopteninae. Although wild animals seem to be the preferred hosts of these parasitic arthropods, it is increasingly being noted that humans are also directly threatened by their bites. Lipoptena species (e.g., Lipoptena cervi Linnaeus, 1758 and Lipoptena fortisetosa Maa, 1965), named the deer keds or deer flies, are commonly encountered in temperate areas of Europe, Siberia, northern China, and North America [1-3]. Both male and female adults are the only developmental stages that feed on blood. They parasitize mainly on wild ruminants, e.g., moose and deer burrowing through the fur and sucking the blood of the animal host.

Despite the relatively high veterinary and medical importance and increasing abundance of Lipoptena in Europe, the biology of these species requires further research [3,4]. Lipoptena cervi is a common species in most European countries; however, it was officially recorded on cervids in Turkey in 2007-2010 [5] and on European roe deer (Capreolus capreolus) in the north-eastern region of Romania in 2014 [6]. In Poland, the species is distributed throughout the country [7], and its dynamic spread and the nuisance caused to people seem to be increasing in recent years. A massive attack of L. cervi in Poland was documented as early as 1975 in the Niepołomicka Forest, where attacks by up to 20-30 adult individuals per human were observed within $5 \mathrm{~min}$ [8]. Humans are accidental hosts for Lipoptena species, as they cannot reproduce after feeding on humans. For this reason, this is even considered an ecological trap $[9,10]$, because when the parasite settles on the host, it loses its wings.

Lipoptena fortisetosa is a species typical of Asian deer: the Siberian roe deer (Capreolus pygargus) and the eastern deer (Cerous nippon) [11,12]. The first reports of its presence in Europe came in the 1960s [7], and its progressive range expansion has been observed over the past years $[13,14]$. In Poland, the first observations of L. fortisetosa were made in Lower Silesia at the end of the 1980s [15]. Earlier, in extensive studies carried out by Kadulski from 1973-1980, only L. cervi was recorded in Poland (cited after [7]). L. fortisetosa was observed again in 2007-2012 on red deer and roe deer in the north of the country [16,17] and in natural habitats located in north-eastern and southern Poland, including the Polish part of the Tatra Mountains [18,19].

Depending on the geographical region, climate, and ecological conditions, the prevalence and severity of invasion of ectoparasites vary significantly, e.g., in the case of L. cervi, it mainly depends on the host species [20] and seasonal differences. The highest prevalence is most often noted in autumn and winter [21,22]. Depending on the geographical region, there are differences among the main hosts of Lipoptena species. For example, moose is the main host for L. cervi in Scandinavia, and Cervus elaphus and Capreolus capreolus are indicated as important hosts of this species in different regions of Europe [2,14,16,23-25] (own observations). In contrast, there are no clear data on the dominant host of L. fortisetosa, although it is suggested that this role is probably played by roe deer [7].

A single host may be infested by up to 17,000 Lipoptena specimens, and their most frequent and most intense infestation was found in moose, with the prevalence of infection reaching even $80-100 \%[4,26,27]$. Such massive invasions of L. cervi in Scandinavia were regarded as one of the factors causing a deadly disease called the "hair loss syndrome" in moose [28]. The increase in the number of $L$. cervi may correlate with the increase in the population size of moose, which plays the role of its main host in Finland [4,23]. Given the ban imposed on moose hunting in Poland in 2001 resulting in a gradual increase in the number of moose, deer ked attacks may also become a problem in the Polish moose population soon.

Lipoptena species pose a threat to the health of the host as potential vectors of numerous pathogens. The greatest epidemiological importance is attributed to Bartonella schoenbuchensis, Borrelia burgdorferi, and Anaplasma phagocytophilum [29-34] as well as Trypanosoma (Megatrypanum) spp. $[14,35]$. People entering natural habitats of Lipoptena spp. are exposed to their attacks and the subsequent health consequences; therefore, knowledge of the clinical picture of Lipoptena bites may be helpful in proper diagnosis and further therapeutic management. In the literature on the subject, publications describing skin lesions in patients rarely contain photographic documentation, valuable in the diagnostic process. In our opinion, knowledge of symptoms caused by Lipoptena bites is worth promoting among not only scientists but also the general public. 


\section{Materials and Methods}

Skin lesions resulting from Lipoptena bites on a member of our research team were documented using a camera in a HUAWEI Y6 Prime 2018 smartphone (Huawei Technologies Co., Ltd., Shenzhen, China) and described by a specialist in dermatology. Identification of the insect species and the developmental stage was carried out using an OLYMPUS SZX16 (Olympus, Tokyo, Japan) stereoscopic microscope and the key to the identification of arthropod species by Borowiec [1].

\section{Results}

\subsection{Environmental Background and Circumstances of Lipoptena cervi Bites}

A 35-year-old woman was walking near a coniferous forest inhabited by numerous wild animals, e.g., deer and roe deer, and moose. Specimens of Lipoptena spp. had been observed in this area since spring (grasslands of 2.5 ha, being an ecotone inside coniferous forest complexes in the Puławy State Forest, Eastern Poland). The woman was bitten six times on her left thigh during 45 min contact with the ectoparasite in a car on July afternoon. The parasites got into the car and attacked the woman. The bites by the insect moving on the woman's legs were painless. It is interesting how the specimen described did not lose its wings after reaching the human host and continued biting. The insect was caught and placed in a plastic container for further investigations.

\subsection{Case Presentation}

The first itching and burning symptoms appeared at night. At 8 a.m., six disseminated urticarial pink papules (the biggest at the time was $15 \mathrm{~mm} \times 25 \mathrm{~mm}$ ) on an erythematous base were noticed on the thigh (Figure 1A). The deer ked feeding site was visible in the central part of the lesions. Precisely $25 \mathrm{~h}$ after biting, the papules became more regular, but with the presence of a severe allergic reaction (Figure 1B). 

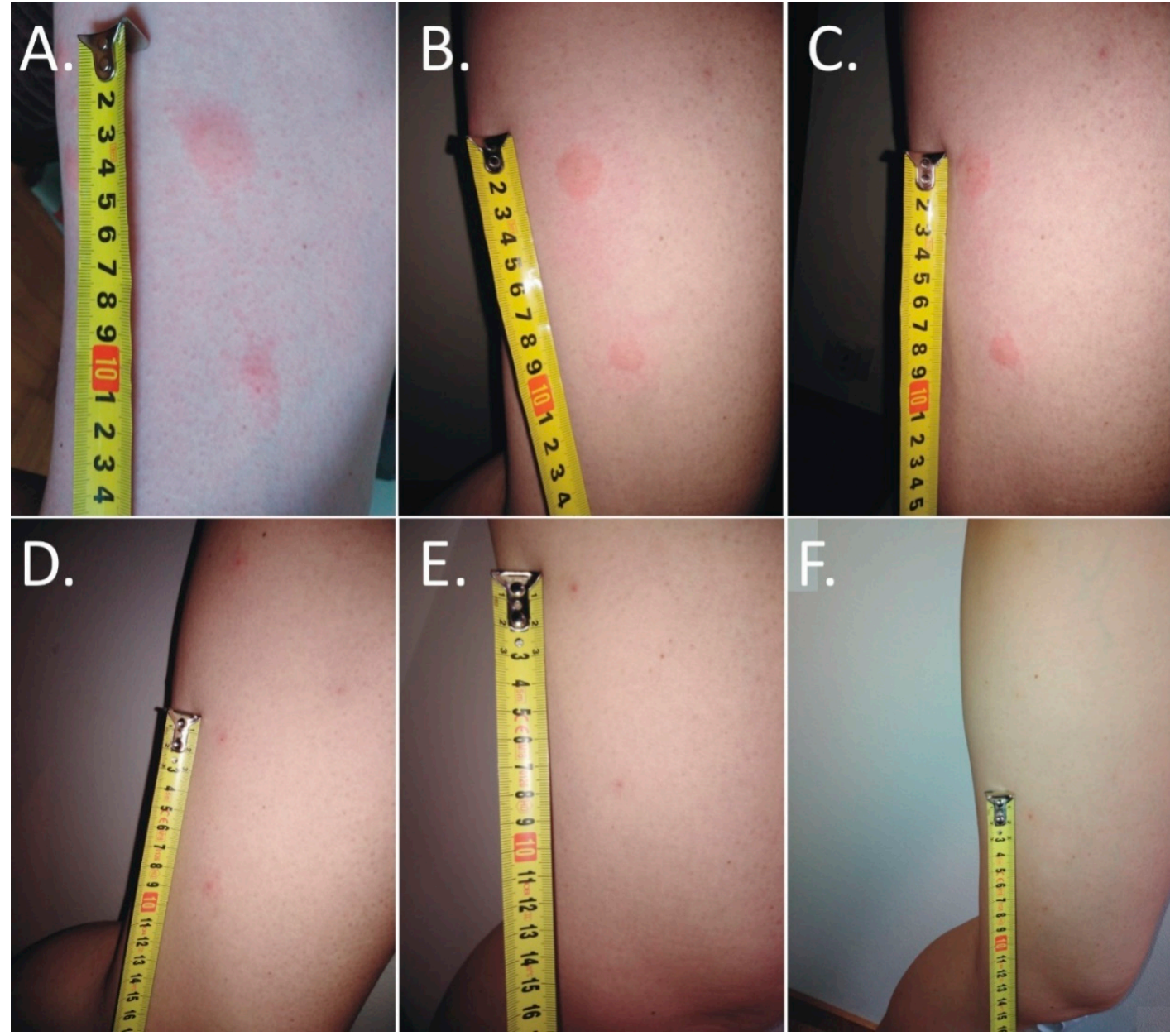

Figure 1. Evolution of skin lesions after deer ked (Lipoptena cervi) bites. (A,B) Multiple painful urticarial pink papules on an erythematous base on the thigh: (A) irregular one day after the bite; (B) more regular two days after the bite); (C) excoriated erythematous papules with self-limited dermatitis (three days after the bite); (D) hyperpigmented papules on an erythematous base (5 days after the bite); (E) hyperpigmented papules on an erythematous base (4 weeks after the bite); (F) residual hyperpigmented papules 6 weeks after the bite).

The skin lesions caused an increasing burning pain. During the following days, the inflammatory reaction was observed to have spread. Three days after the bite, the dermatitis showed a self-limiting tendency (Figure 2). Excoriated erythematous papules appeared in the center of the site of the deer ked bite. The inflammatory reaction resolved over five days, but hyperpigmented papules persisted for three months. In only the biggest site of the deer ked bite, a small field with a clear fluid vesicle was noticed. The Lipoptena cervi bites caused the formation of vesicles on the skin, which transformed into small erosions after splitting (Figure 3). The patient did not report any additional systemic symptoms. The patient did not use any ointment to relieve the symptoms, but she only took antihistamines (20 mg of bilastine, and $10 \mathrm{mg}$ of cetirizine once a day) for ten days. The skin lesions were not touched or scratched. The woman underwent diagnostic IFA tests for the detection of Bartonella spp. IgM and IgG as well as ELISA tests for the detection of Borrelia burgdorferi s.l. IgM and IgG. The results showed abnormalities that required further monitoring. 


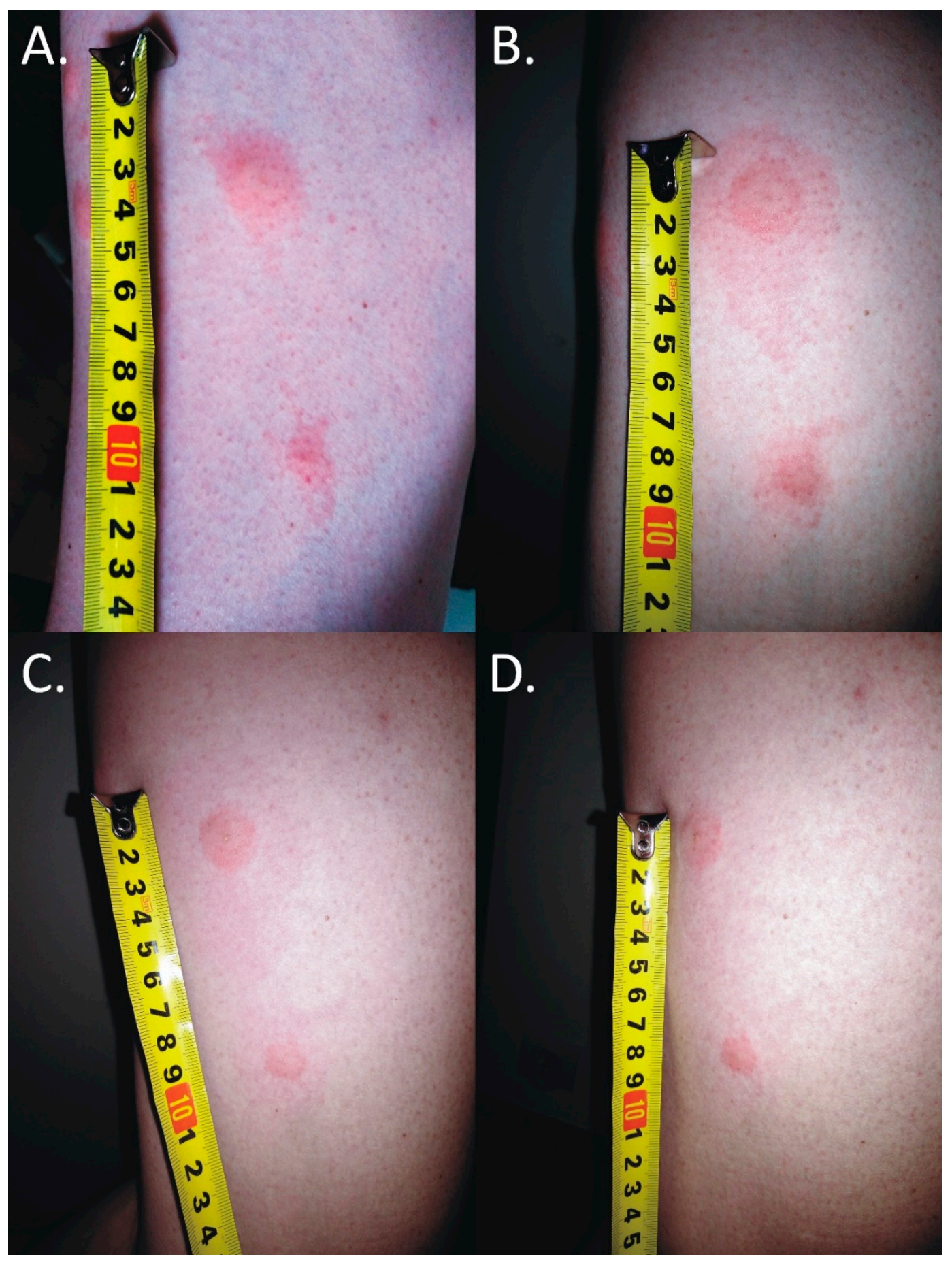

Figure 2. Inflammatory reaction to the deer ked (Lipoptena cervi) bite. (A) $25 \mathrm{~mm} \times 15 \mathrm{~mm}$ erythema $17 \mathrm{~h}$ after the bite; (B) $50 \mathrm{~mm} \times 25 \mathrm{~mm}$ erythema $25 \mathrm{~h}$ after the bite; (C) $68 \mathrm{~mm} \times 30 \mathrm{~mm}$ erythema $40 \mathrm{~h}$ after the bite; (D) self-limited $50 \mathrm{~mm} \times 30 \mathrm{~mm}$ inflammatory reaction $64 \mathrm{~h}$ after the bite; the black lines mark the extent of inflammatory changes. 


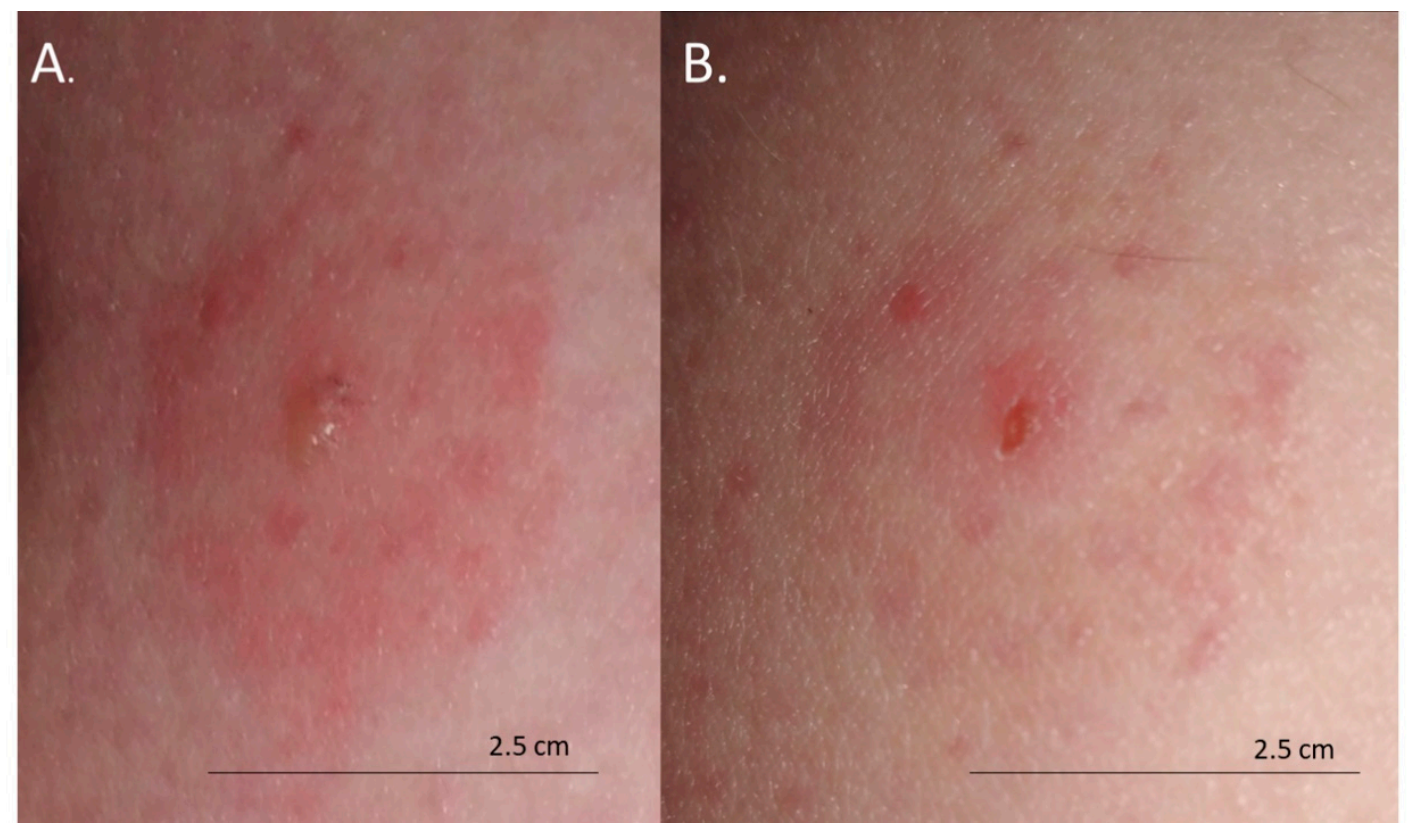

Figure 3. Bites from deer ked (Lipoptena cervi): (A) formation of vesicles on the skin $48 \mathrm{~h}$ after the bite; (B) small erosions $72 \mathrm{~h}$ after the bite.

\subsection{Insect Identification}

During identification and photo works, the wings of the ked dropped off. The insect was identified as a Lipoptena cervi female (Figure 4).

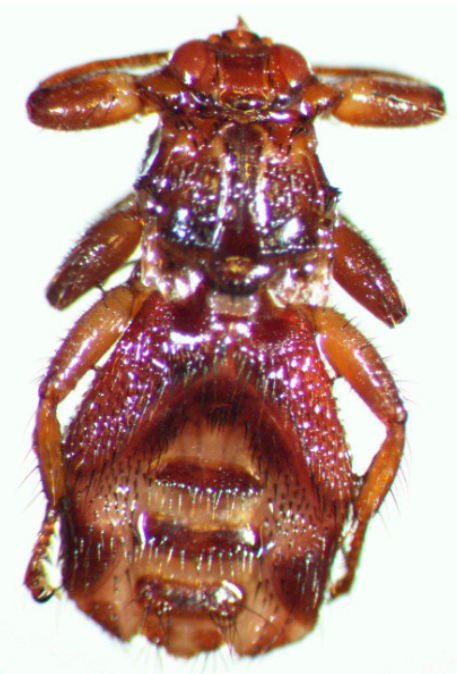

(A)

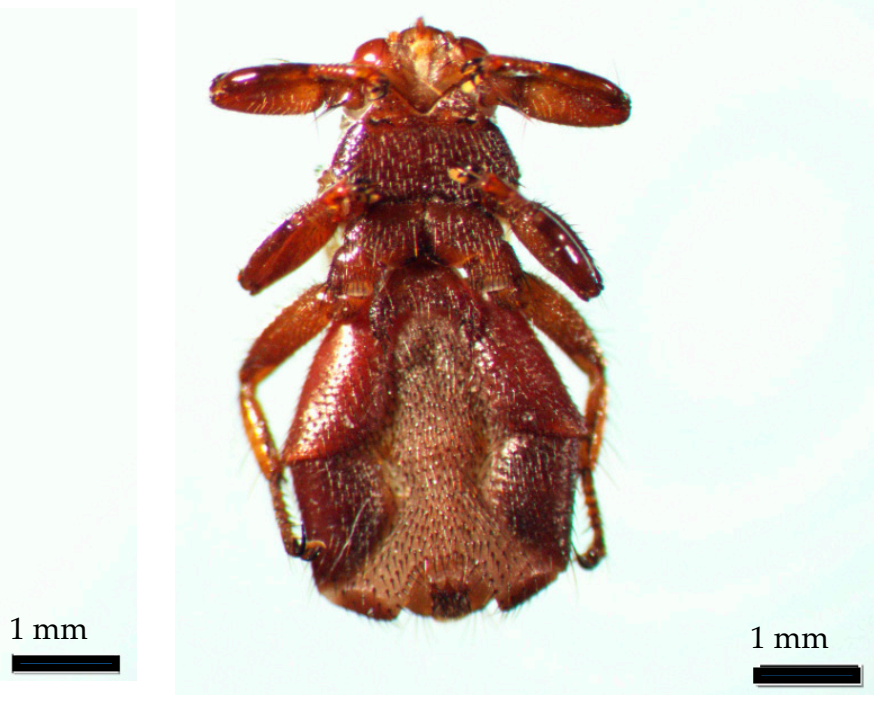

(B)

Figure 4. Lipoptena cervi female: (A) dorsal view; (B) ventral view.

\section{Discussion}

Animals and people living or staying for professional and recreational purposes in habitats of parasites are exposed to attacks and infections by ked-transmitted pathogens. The risk is mainly related to the type of environment inhabited by the population of susceptible hosts and is a serious problem for professional groups staying constantly or frequently in the natural environment and threatened directly by zoonotic diseases transmitted by ticks. The problem becomes particularly important in the era of 
climate change. The increase in average temperatures and the shorter winter periods significantly affect the expansion of ectoparasites, which show high flexibility and the ability to adapt to gradual changes in thermal conditions [22,36,37]. Their spread is also facilitated by the high density of biungulates related to the almost unlimited access to crops and agricultural produce they feed on.

In cervids, anemia and mechanical damage were suggested as clinical symptoms of heavy infestation [38]. Infestation can induce scratching and itching in animals, and this may impair the condition of the host following secondary bacterial infection [29]. The growing problems caused by Lipoptena species in Scandinavia, especially in Finland, have been documented [23,27]. In some cases, serious disease symptoms and health problems have been noted in humans, including chronic dermatitis [39] and occupational allergic rhinitis and conjunctivitis [40]. In turn, pricks of another Hippoboscidae representative, Hippobosca equina, may be a cause of anaphylactic shock in humans [41]. The situation is additionally complicated by the lack of repellents operating effectively against Lipoptena species.

The direct effects of parasitic arthropod bites (i.e., changes caused by the arthropod itself, e.g., through the action of salivary components or mechanical damage to the skin by the mouth organs) may include local inflammatory reactions or chronic skin inflammation [29]. Skin lesions evolving after Lipoptena bites are painful and often lead to the development of inflammation of the skin, characterized by the presence of characteristic clots accompanied by pruritus [39] (own observations). What is important in the aspect of health protection, due to the short time of the parasitism of Lipoptena spp. on humans and an initially small trace at the bite, is that symptoms reported by the patient are often not associated with infection transmitted by these species [29]. In humans and animals infected with Bartonella schoenbuchensis, moderate to severe skin inflammation can develop with a change that can persist for up to a year $[29,39,42,43]$.

Employees of national parks, forest districts, border guard units, members of hunting associations, researchers, field employees of national environmental service institutions, naturalists, or tourist guides are particularly exposed to infestation of ectoparasites and dermatitis [44,45]. Permanent and numerous Hippoboscidae attacks can therefore hinder forestry work and reduce the recreational value of the area and limit its side-use (harvesting forest fruits, mushroom picking, and recreational activities e.g., sport) [4,44]. Companion animals such as dogs in forest areas are also exposed to Lipoptena attacks, in particular hunting dogs. Parasites may stay on their skin for a long time, causing inflammatory changes [42,45].

\section{Conclusions}

Considering the health consequences of deer ked bites related to the transmission of zoonotic agents, the knowledge of this subject should be disseminated among people who are exposed to their attacks. Both veterinarians and healthcare professionals should be aware that their animal and human patients should be monitored for signs of disease after deer ked bites.

Author Contributions: Conceptualization, W.M. and K.B.; methodology, W.M.; writing—original draft preparation, W.M., M.R.-F., E.S., and M.A.; writing—review and editing K.B.; visualization, W.M. and K.B.; supervision, W.M. All authors have read and agreed to the published version of the manuscript.

Funding: This research received no external funding.

Conflicts of Interest: The authors declare no conflict of interest.

\section{References}

1. Borowiec, L. Keys for Identification of Polish Insects; Polish Entomological Society PWN: Warszawa, Poland, 1984; pp. 1-40. (In Polish)

2. Samuel, W.M.; Madslien, K.; Gonynor-McGuire, J. Review of deer ked (Lipoptena cervi) on moose in Scandinavia with implications for North America. Alces 2012, 48, 27-33. 
3. Bezerra-Santos, M.A.; Otranto, D. Keds, the enigmatic flies and their role as vectors of pathogens. Acta Trop. 2020, 209, 105521. [CrossRef]

4. Kortet, L.; Hãrkõnen, L.; Hokkanen, P.; Hãrkõnen, S.; Kaitala, A.; Kaunisto, S.; Laaksonen, S.; Kekãlaãinen, J.; Ylõnen, H. Experiments on the ectoparasitic deer ked that often attacks humans; preferences for body parts, colour and temperature. Bull. Entomol. Res. 2010, 100, 279-285. [CrossRef]

5. Aḉici, M.; Bölükbas, C.S.; Beyhan, Y.E.; Pekmezci, G.Z.; Gürler, A.T.; Umur, S. Ectoparasites on roe deer (Capreolus capreolus) in Samsun, Turkey. Turk. J. Vet. Anim. Sci. 2012, 36, 456-459.

6. Lazăr, M.; Iacob, O.C.; Solcan, C.; Pașca, S.A.; Lazăr, R.; Boișteanu, P.C. The first report of massive infestation with Lipoptena cervi (Diptera: Hippoboscidae) in Roe Deer (Capreolus capreolus) in Iasi county, N-E of Romania. Arq. Bras. Med. Vet. Zootec. 2014, 69, 293-298. [CrossRef]

7. Kowal, J.; Nosal, P.; Kornaś, S.; Wajdzik, M.; Matusek, M.; Basiaga, M. Biodiversity and importance of hippoboscids infection in cervids. Med. Weter. 2016, 72, 745-749. (In Polish)

8. Starzyk, J. Deer's fly, Lipoptena cervi (L.) (Diptera, Hippoboscidae), an ectoparasite of Artiodactyla. Przegl. Zool. 1975, 17, 446-448. (In Polish)

9. Robertson, B.A.; Hutto, R.L. A framework for understanding ecological traps and an evaluation of existing evidence. Ecology 2006, 87, 1075-1085. [CrossRef]

10. Kaunisto, S.; Korter, R.; Härkönen, L.; Härkönen, S.; Ylönen, H.; Laaksonen, S. New bedding site examination-based method to analyse deer ked (Lipoptena cervi) infection in cervids. Parasitol. Res. 2009, 104, 919-925. [CrossRef]

11. Danilkin, A.A. Capreolus pygargus. Mamm. Species 1995, 512, 1-7. [CrossRef]

12. Maa, T.C. A synopsis of the Lipopteninae. J. Med. Entomol. 1965, 2, 233-248. [CrossRef]

13. Kurina, O.; Kirik, H.; Ounap, H.; Õunap, E. The northernmost record of a blood-sucking ectoparasite, Lipoptena fortisetosa Maa (Diptera: Hippoboscidae), in Estonia. Biodivers. Data J. 2019, 7, 47857. [CrossRef]

14. Werszko, J.; Steiner-Bogdaszewska, Ż.; Jeżewski, W.; Szewczyk, T.; Kuryło, G.; Wołkowycki, M.; Wróblewski, P.; Karbowiak, G. Molecular detection of Trypanosoma spp. in Lipoptena cervi and Lipoptena fortisetosa (Diptera: Hippoboscidae) and their potential role in the transmission of pathogens. Parasitology 2020, 1, 1-7. [CrossRef]

15. Borowiec, L.; Zatwarnicki, T. Lipoptena fortisetosa Maa, 1965 (Diptera, Hippoboscidae), a new species of Polish fauna. Przegl. Zool. 1989, 33, 579-582.

16. Cydzik, K.; Kadulski, S. Parasitic Insects of the Red Deer (Cervus elaphus L.) inthe Northern Poland. In Arthropods. Invasions and Their Control; Buczek, A., Błaszak, C., Eds.; Akapit: Lublin, Poland, 2009; pp. 59-66.

17. Jedrysik, D.; Kadulski, S. Parasitic Arthropods of Roe Deer Capreolus capreolus (L.) of the Region of The Southern Baltic Lake District. In Arthropods. The Medical and Economic Importance; Buczek, A., Błaszak, C., Eds.; Akapit: Lublin, Poland, 2012; pp. 95-103.

18. Kowal, J.; Nosal, P.; Rościszewska, M.; Matysek, M. New records of Lipoptena fortisetosa Maa, 1965 (Diptera: Hippoboscidae) in Poland. Dipteron 2009, 25, 27-29. (In Polish)

19. Matysek, M.; Kowal, J. Two new species of Diptera. Tatry 2014, 48, 64-65. (In Polish)

20. Välimäki, P.; Kantala, A.; Madslien, K.; Härkönen, L.; Várkonyi, G.; Heikkilä, J.; Jaakola, M.; Ylönen, H.; Kortet, R.; Ytrehus, B. Geographical variation in host use of a blood-feeding ectoparasitic fly: Implications for population invasiveness. Oecologia 2011, 166, 985-995. [CrossRef]

21. Kadulski, S. The dynamics of infestation of the Cervidae with Lipoptena cervi L. (Diptera, Hippoboscidae) on the territory of Poland. Wiad. Parazytol. 1974, 20, 703-707. (In Polish)

22. Mysterud, A.; Madslien, K.; Herland, A.; Viljugrein, H.; Ytrehus, B. Phenology of deer ked (Lipoptena cervi) host-seeking flight activity and its relationship with prevailing autumn weather. Parasit. Vectors 2016, 9, 95. [CrossRef]

23. Kaitala, A.; Kortet, R.; Härkönen, S.; Laaksonen, S.; Härkönen, L.; Kaunisto, S.; Ylönen, H. Deer ked, an ectoparasite of moose in Finland: A brief review of its biology and invasion. Alces 2009, 45, 85-88.

24. Haarløv, N. Life cycle and distribution pattern of Lipoptena cervi (L.) (Dipt., Hippobosc.) on Danish deer. Oikos 1964, 15, 93-129. [CrossRef]

25. Madslien, K.; Ytrehus, B.; Viljugrein, H.; Solberg, E.J.; Bråten, K.R.; Mysterud, A. Factors affecting deer ked (Lipoptena cervi) prevalence and infestation intensity in moose (Alces alces) in Norway. Parasit. Vectors 2012, 5, 251. [CrossRef] 
26. Kadulski, S. Further studies on parasitic arthropods of elk Alces alces from Poland. Wiad. Parazytol. 1996, 42, 349-355. (In Polish)

27. Välimäki, P.; Madslien, K.; Malmsten, J.; Härkönen, L.; Härkönen, S.; Kaitala, A.; Kortet, R.; Laaksonen, S.; Mehl, R.; Redford, L.; et al. Fennoscandian distribution of an important parasite of cervids, the deer ked (Lipoptena cervi), revisited. Parasitol. Res. 2010, 107, 117-125. [CrossRef]

28. Madslien, K.; Ytrehus, B.; Vikøren, T.; Malmsten, J.; Isaksen, K.; Hygen, H.O.; Solberg, E.J. Hair-loss epizootic in moose (Alces alces) associated with massive deer ked (Lipoptena cervi) infestation. J. Wildl. Dis. 2011, 47, 893-906. [CrossRef]

29. Dehio, C.; Sauder, U.; Hiestand, R. Isolation of Bartonella schoenbuchensis from Lipoptena cervi, a blood-sucking arthropod causing deer ked dermatitis. J. Clin. Microbiol. 2004, 42, 5320-5323. [CrossRef]

30. Halos, L.; Jamal, T.; Millard, L.; Girard, B.; Guillot, J.; Chomel, B.; Vayssier-Taussat, M.; Boulouis, H.J. Role of Hippoboscidae flies as potential vectors of Bartonella spp. infecting wild and domestic ruminants. Appl. Environ. Microbiol. 2004, 70, 6302-6305. [CrossRef]

31. Víchová, B.; Majláthová, V.; Nováková, M.; Majláth, I.; Čurlík, J.; Bona, M.; Komjáti-Nagyová, M.; Pet’ko, B. PCR detection of re-emergingtick-borne pathogen, Anaplasma phagocytophilum, in deerked (Lipoptena cervi) a blood-suckingectoparasite of cervids. Biologia 2011, 66, 1082-1086. [CrossRef]

32. De Bruin, A.; Van Leeuwen, A.D.; Jahfari, S.; Takken, W.; Földvári, M.; Dremmel, L. Vertical transmission of Bartonella schoenbuchensis in Lipoptena cervi. Parasit. Vectors 2015, 8, 176. [CrossRef]

33. Buss, M.; Case, L.; Kearney, B.; Coleman, C.; Henning, J.D. Detection of Lyme disease and anaplasmosis pathogens via PCR in Pennsylvania deer ked. J. Vector Ecol. 2016, 41, 292-294. [CrossRef]

34. Szewczyk, T.; Werszko, J.; Steiner-Bogdaszewska, Ż.; Jeżewski, W.; Laskowski, Z.; Karbowiak, G. Molecular detection of Bartonella spp. in deer ked (Lipoptena cervi) in Poland. Parasit. Vectors 2017, 10, 487. [CrossRef]

35. Böse, R.; Petersen, K. Lipoptena cervi(Diptera), a potential vector of Megatrypanum trypanosomes of deer (Cervidae). Parasitol. Res. 1991, 77, 723-725. [CrossRef]

36. Boeckmann, M.; Joyner, T.A. Old health risks in new places? An ecological niche model for I. ricinus tick distribution in Europe under a changing climate. Health Place 2014, 30, 70-77. [CrossRef]

37. Földvári, G.; Široký, P.; Szekeres, S.; Majoros, G.; Sprong, H. Dermacentor reticulatus: A vector on the rise. Parasit. Vectors 2016, 9, 314. [CrossRef]

38. Allan, S.A. Biting Flies (class Insecta: Order Diptera). In Parasitic Diseases of Wild Mammals, 2nd ed.; Samuel, W.M., Pybus, M.J., Kocan, A.A., Eds.; Iowa State University Press: Ames, IO, USA, 2001; pp. $18-45$.

39. Rantanen, T.; Reunala, T.; Vuojolahti, P.; Hackman, W. Peristent pruritic papules from deer ked bites. Acta Derm. Venereol. 1982, 62, 307-311.

40. Laukkanen, A.; Ruoppi, P.; Mäkinen-Kiljunen, S. Deer ked-induced occupational allergic rhinoconjunctivitis. Ann. Allergy Asthma Immunol. 2005, 94, 604-608. [CrossRef]

41. Decastello, A.; Farkas, R. Anaphylactic reaction following forest fly (Hippobosca equina) bite: A human case. Clin. Exp. Med. J. 2010, 4, 193-198. [CrossRef]

42. Hermosilla, C.; Pantchev, N.; Bachmann, R.; Bauer, C. Lipoptena cervi (deer ked) in two naturally infested dogs. Vet. Rec. 2006, 159, 286-287. [CrossRef]

43. Matsumoto, K.; Berrada, Z.L.; Klinger, E.; Goethert, H.K.; Telford, S.R. Molecular detection of Bartonella schoenbuchensis from ectoparasites of deer in Massachusetts. Vector Borne Zoonotic Dis. 2008, 8, 549-554. [CrossRef]

44. Härkönen, S.; Laine, M.; Vornanen, M.; Reunala, T. Deer ked (Lipoptena cervi) dermatitis in humans-An increasing nuisance in Finland. Alces 2009, 45, 73-79.

45. De Keukeleire, M.; Vanwambeke, S.O.; Somassè, E.; Kabamba, B.; Luyasu, V.; Robert, A. Scouts, forests, and ticks: Impact of landscapes on human-tick contacts. Ticks Tick Borne Dis. 2015, 6, 636-644. [CrossRef]

Publisher's Note: MDPI stays neutral with regard to jurisdictional claims in published maps and institutional affiliations. 